\section{Fossil fuels' future}

The 27 June special section on The Great Gas Boom ("The gas surge," D. Malakoff, p. 1464) about natural gas from hydraulic fracturing provided a useful update on a range of important environmental, social, and economic issues, with the exception of the elephant in the room: Natural gas is a fossil fuel. While a natural gas-fired power station has fewer $\mathrm{CO}_{2}$ emissions per unit energy produced compared with a coalfired power station (up to $50 \%$ if fugitive emissions are captured or ignored) ("Hunting a climate fugitive," E. Kintisch, p. 1472), this is largely irrelevant to solving the climate change problem. What matters is the long-term accumulated stock of carbon in the atmosphere, not the shortterm rate of emissions (3). The relationship between cumulative emissions and peak warming is insensitive to timing of emissions or peak emission rate (4). The lifetime of the airborne fraction of a pulse of fossil fuel-derived $\mathrm{CO}_{2}$ is much longer than the centuries some authors still believe (as stated in the News story by Kintisch). Modeling reveals that 20 to $35 \%$ of the $\mathrm{CO}_{2}$ emitted now will still be in the atmosphere after 2 to 20 millennia (5). To have a greater than $66 \%$ chance of limiting global warming to less than $2^{\circ} \mathrm{C}$ above the pre-industrial average surface temperature (6), humanity can emit only a further 275 Gt C, or about 34 years of "business-asusual" emissions (7). The harsh reality is that $\mathrm{CO}_{2}$ emissions must decrease to zero before the end of this century or we will likely exceed the $2^{\circ}$ guard rail. In these circumstances, it is difficult to envisage a future where both the climate change problem is resolved and today's fossil fuel industry persists.

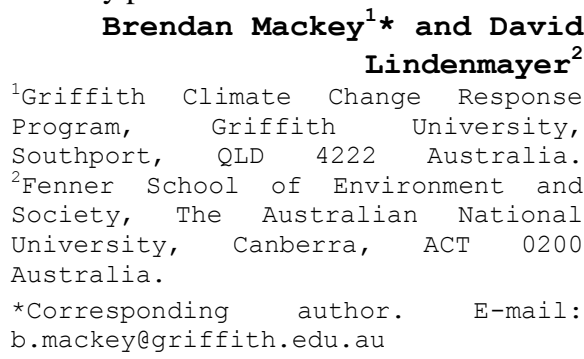

\section{References}

3. B. Mackey et al., Nat. Clim. Change 3, 552 (2013).

4. M. R. Allen et al., Nature 458, 1163 (2009).
5. D. Archer et al., Annu. Rev. Earth Planet. Sci. 37, 117 (2009).

6. United Nations Framework Convention on Climate Change, Report of the Conference of the Parties on its 15 th session, held in Copenhagen from 7 to 19 December 2009, Addendum, Part Two: Action taken by the Conference of the Parties at its 15th session (UNFCCC, FCCC/CP/2009/11/Add.1, 30 March 2010);

http://unfccc.int/meetings/copenhage n_dec_2009/items/5262.php.

7. T. F. Stocker et al., Eds. IPCC, 2013: Summary for Policymakers in Climate Change 2013: The Physical Science Basis. Contribution of Working Group I to the Fifth Assessment Report of the Intergovernmental Panel on Climate Change (Cambridge Univ. Press, Cambridge, UK, 2013). 